\title{
TEACHING ENGLISH AS A FOREIGN LANGUAGE: A CASE STUDY FROM POLAND
}

\author{
JAROSLAW R. ROMANIUK ${ }^{1}$, KRISTIN MILLER ${ }^{2}$, MARY KAY PIESKI ${ }^{3}$, TERESA G. \\ WOJCIK $^{4}$, \& KATHLEEN J. FARKAS 5
}

\footnotetext{
${ }^{1}$ Case Western Reserve University, Jack, Joseph and Morton Mandel School of Applied Social Sciences, 11235 Bellflower Road, Cleveland, OH, 44106, US. ORCID: 0000-0002-8568-6587, Email: irr3@case.edu

2 Oberlin City Schools, 153 N Main St, Oberlin, OH 44074, US. ORCID: 0000-0003-2711-8204, Email: kmiller@oberlinschools.net

${ }^{3}$ Kent State University, 800 E. Summit St., Kent, OH, 44242, US. ORCID: 0000-0001-7078-4507, Email: mpieski@kent.edu

${ }^{4}$ Villanova University, 800 Lancaster Ave, Villanova, PA, 19085, US. ORCID: 0000-0001-6676-655X, Email: teresa.wojcik@villanova.edu

${ }^{5}$ Case Western Reserve University, Jack, Joseph and Morton Mandel School of Applied Social Sciences, 11235 Bellflower Road, Cleveland, OH, 4106, US. ORCID: 0000-0002-1937-3603, Email: kjf@case.edu
}

\begin{abstract}
This article presents a detailed history of the development of a particular immersion program to teach English to young Polish students. The program draws support from two organizations, the Kościuszko Foundation and the Polish Scouting Organization. Kościuszko Foundation is dedicated to strengthening the ties between the United States and Poland as well as to increase knowledge of Poland's history and culture in the United States. The cooperation of these two organizations developed an experience of immersion in language and cultural exchange. Both the teachers and the students in this program benefited from the opportunity to engage in a number of different types of language activities and cultural events through a summer camp experience. This program is, of course, unique, but the elements of context, culture and immersion could be used in other programs to develop English skills and knowledge in the context American culture.
\end{abstract}


KEYWORDS: Teaching English; immersion language, language program history, Polish-United States exchange

\section{INTRODUCTON}

This article describes a program that teaches English as a foreign language in the context of United States cultural practices and historical events set in a summer scout camp for Polish elementary school children. Since the early 1990's the Kosciuszko Foundation (KF) has organized and staffed 144 English Language American Culture and Arts Enriched Camps throughout Poland. More than 15,000 Polish students, approximately 2,500 American volunteer teachers and assisting students and a comparable number of Polish educators and student counselors have benefitted from participation in this program. The focus of this paper is the program located in Załęcze Wielkie, established by the Kościuszko Foundation. A unique element of the Załęcze Wielkie program, is the cooperation with the Polish Scouting Organization (ZHP). Kosciuszko Foundation supports a number of camp programs that teach STEM, but the Zalecze Wielkie camp is the only one that cooperates with ZHP. The presented model was developed by an American non-profit organization (KF), volunteers and Polish public organizations; however, we argue the model may be more widely generalized and reproduced. While this model has been described as a language teaching tool, the authors highlight the interdisciplinary aspects, involving volunteer teachers and social workers, may increase children's skills and openness to opportunities of globalized work (Devereux 2008). The Teaching English in Poland Program of the Kościuszko Foundation is a unique program developed by responding to needs with available resources. We present the history of this endeavor to acknowledge the work of the Kościuszko Foundation as well as to inform future educators and innovators.

\section{TEACHING ENGLISH IN POLAND AFTER 1989}

After the Second World War, the education program in Poland was introduced under the influence of the Soviet Union. The main second language taught in Poland was Russian and was mandatory in all Polish schools. Although some schools also offered a third language, usually English, German, French, or Spanish, it was rare for schools to offer a third language option. After 1989, when as a result of the Solidarity movement Poland regained freedom to self-govern, new education programs provided flexibility for schools to select programs and texts in the language of their choice. The role of Russian as a second language decreased in favor of English; language choice became a symbol of the new direction of a country moving toward "freedom, democracy and wealth" (Komorowska 2014). However, there was a pronounced shortage of teachers able to teach English as a second language. The first response to this situation was to educate a significant number of teachers in a relatively short time. Many teachers of other specialties (especially teachers of Russian) were encouraged to learn new skills and become teachers of English as an international language. 
Poland's new open attitude to the West after 1989 allowed people to develop their life goals in a more globalized world and for this reason knowledge of English became important. Poles began to travel to the West looking for work, others learned new careers and experienced a world that, for years, was out of reach. Knowledge of English became crucial for people to meet their new life goals and people quickly recognized its significance in everyday life (Kasztalska 2014). Just after 1989 there were 18,000 Russian teachers in Poland, more than ten times the number of English teachers. Twenty years later, in 2009/2010, ninety percent of students in the school system were already studying English. Only $7.2 \%$ studied Russian language (data from Komorowska 2014). In 2010-2011 there were 3,414 teachers of English and 3,580 teachers of Russian in Poland. (Zarebska 2010/2011).

\section{DEVELOPING NEW MODELS OF TEACHING ENGLISH}

One of the concerns of teaching an international language is the message transmitted during that process. In the case of Russian, it was clear that the teaching of this language had also been a venue for Soviet propaganda. Political and social messages that would have been difficult to deliver in other classes were presented naturally under the cover of teaching Russian. Russian language instruction was the most effective way for students to learn about the literature and art of the Soviet Union in the twentieth century. Similarly, people often have asked if teaching English as a international language can be a form of cultural imperialism, a way to present Western culture as superior to others (Odrowąż-Coates 2017). It would be difficult to teach a language without also engaging in discussions about the culture in which the language operates and often these discussions - either overtly or covertly- include social and political opinions.

In the years 1945-1989, when the Soviet Union had significant influence on the content and methods of teaching in Polish schools, the educational needs of certain groups of Polish citizens were not met. Among those needs was the knowledge of the English language. Those with professional or personal interests in learning English, had few options and many of these options were expensive. English classes were offered, for example, by the Methodist Church or language camps were offered by British Council (Swick 1991; Hayes 2014). Participation in any activities to learn English, including private lessons offered by skillful teachers, was desirable and prestigious, but typically carried a high cost. Knowledge of English provided many benefits for those Polish residents who learned it. For example, they could have contacts with people visiting from Western countries, listen to and understand radio broadcasts and read literary sources not available to the general public. A knowledge of English allowed young people to listen to and understand modern music, which gained enormous interest beginning in the 1960's and continues even today. In Poland's rebellious culture towards Soviet propaganda, the motivation to learn English was very high, but there were many barriers to realizing the goal of understanding and speaking English.

There are many models of language education concerning the most effective way to engage students in the process of learning (Dörnyei 1998; Guerrero 2015). The tra- 
ditional model of teaching a foreign language at school is whole class instruction offered by a teacher from the same community as the students. Often, English language texts are available in Polish so instruction and communication between students and a teacher is based on translation of words using the same communication structure as in other classes. Less traditional models of language instruction are related to understanding the motivation to learn a language. Gardner and Lambert (1972) described two different approaches in the process of learning language: an integrative orientation that encompasses a language, its culture, and its community and instrumental orientation that is related to practical goals of learning. Further, research in language acquisition addresses the cognitive processes and the learning context in the class. The last sphere of research concerns a specific learner's motivations which change over the time of learning and understanding the benefits of acquiring new linguistic skills (Guerrero 2015). The traditional model of learning English as an international language in schools, by rote memorization and grammar study, does not offer an integrative component of motivation and attention to a student's practical goals for learning (Kasztalska 2014).

There are several theoretical approaches to characterize the best practices in teaching a language (Brown 2000; Richards and Renandya 2002) and evaluations to support the best practices (Hillocks, 2009). In general, it is difficult to evaluate a process that is multidimensional and time dependent. Motivation to learn a foreign language changes with age and with the understanding of the benefits that knowledge of English offers. The most informative are empirical data gathered in different countries and cultures that develop their own practices and process evaluations of teaching English as a second language (Giota 1995; Nikolov 1999; McKay 2003; Guerrero 2015).

After 1989, with the beginning of political and economic transformation, people in Poland quickly understood that knowledge of English will help them to achieve their personal and career goals. Many teachers had to make a decision to abandon their previous discipline, like teaching Russian, and learn how to teach English. It is obvious that in a short transition period many teachers did not develop desirable teaching skills. Both students and teachers became learners. Instrumental motivation was clear but integrative orientation was more difficult to achieve. Parents of school age children were looking for the best learning environment for them. Many people who had experiences living in English speaking countries offered private classes. Parents who could afford sending their children abroad use this resource to better prepare their children for the new, more competitive word. Again, the need to learn English had a barrier of high financial cost. People were looking for better and more accessible models of teaching English as an international language.

In 1991, the Polish National Commission for UNESCO and the Polish Ministry of National Education invited the Kościuszko Foundation to cooperate in meeting the growing English language needs of Polish youth that emerged after the fall of communism. The Kościuszko Foundation responded with the development of the Teaching English in Poland program (TEIP), an innovative approach providing Polish students (upper elementary through high school) with interactive English language immersion experiences and practice in conversational English within an American cultural con- 
text at summer camps throughout Poland. It also incorporated principles of democracy, entrepreneurship, business etiquette and volunteerism to provide Polish students with the basic tools needed to ease the transition after 1989 to national independence and to prepare them for participation in international arenas. From its inception the program was also intended to give American teacher and student volunteers the opportunity to become acquainted with the people, history, language, culture and educational system of Poland.

The role of the Polish Ministry of National Education (MEN) was to fund the boarding school campuses and educational centers designated as camp sites, to compensate the Polish staffs required to work with the students and Americans, and to cover the costs related to the operation of the camps. Polish camp Directors would also receive funds to provide the American participants with a small stipend, classroom and extra-curricular facilities, room and board, experiences in Polish culture and life, complimentary excursions to local places of historical and cultural interest and an end-of-program tour. The primary responsibilities of the Kościuszko Foundation were to recruit, select, and organize the volunteer American staff for each camp, arrange group flights to Poland, provide a program and curriculum guide and arrange for accident-medical insurance for its American participants.

\section{DETAILED HISTORY OF THE TEACHING ENGLISH IN POLAND PROGRAM}

The Western New York Chapter of the Kościuszko Foundation recruited ten American teachers to implement the 1991 pilot program at a boarding school in Bydgoszcz. One hundred Polish students enrolled in the program that summer. Due to its success, the Kościuszko Foundation expanded the camp offerings the next year. In 1992, Christine B. Kuskowski, Kościuszko Foundation member and Colorado and New York State educator and curriculum specialist, authored and presented the first official Teaching English in Poland program and Curriculum Guide as a volunteer in preparation for leading an American staff and implementing the TEIP program for high school students in Łomża. The guide was also to be used by an American staff from the Western N.Y. Chapter for launching the program at a camp in Ustka. This guide was afterwards revised annually to accommodate the needs of American volunteers and Polish students and to keep in step with changing times and venues.

As the program grew in popularity, Kościuszko Foundation President Joseph E. Gore, Esq. appointed Mrs. Kuskowski as Program Director in 1993. Under Mrs. Kuskowski's vision and leadership, the program expanded rapidly reaching a record high of nine camps per year in the period 1995-1997. As the English language became a popular foreign language in Polish schools, parents clamored to send their children to the camps. At that time, it was presumed that the program would only serve Polish high school students. As studying the English language became a popular option in Polish schools, the TEIP program grew in demand and was opened to upper elementary and junior high school students. The curriculum and model for the upper elementary group was developed by Dr. Mary Kay Pieski in 1997 and was implemented at the Warsaw camp. For the first time, American youth were partnered with Polish students 
and served as peer tutors. The curriculum focused on assisting the students in refining their English language conversational skills, on motivating them to develop self-confidence while applying those skills, and on preparing them to engage in international endeavors.

From 1998-2009, the number of camps ranged from four to seven each year. In 2009, the Polish Ministry of National Education withdrew its financial support from all summer foreign language camps. At this critical juncture, the Kościuszko Foundation decided to continue the program by accepting the invitation of two administrators, who were able to find independent support to organize camps at their sites in 2009 and 2010. These two locations were Załęcze Wielkie and Tczew. In 2009, through the initiative of Assistant Director Mary Kay Pieski, the Foundation introduced the Arts Enriched English Language Camp for students thirteen to fifteen years of age at the Polish Scouts Organization's (ZHP) educational, environmental, and recreational center, "Nadwarciański Gród”, located in Załęcze Wielkie. The traditional TEIP language and American culture program was also conducted simultaneously at that site for upper elementary school students.

Offering an English language camp enriched by the study of the arts represented a truly novel approach for Polish students to learn American culture. Students at this camp attended a total of six different classes taught daily in English. The classes included dance, music, art, storytelling, and drama. Students were accepted into the program regardless of their previous exposure to the arts. The camp provided the opportunity for students to learn how to play banjo, guitar, clarinet, ukulele, dulcimer, and Orff instruments as well as learn choral singing and technology-assisted music composition. The Delta Kappa Gamma Educational Foundation awarded grants, which funded the purchase of these musical instruments. The camp concluded with an Arts Expo for parents, friends, and community members during which the students showcased their work. This innovative camp model was presented at several state, national, and international music education and humanities conferences. In 2010, the Arts Enriched English Language Camp at the ZHP site was expanded to accommodate students twelve through eighteen years of age. The NIDA Foundation of Poland (Nidzicka Fundacja Rozwoju) supported the program by funding the participation of sixty students. The Arts-Enriched English Language and American Culture camp at Załęcze Wielkie was the only TEIP camp offered in 2011.

In 2012, Christine Kuskowski became Director Emerita and Dr. Mary Kay Pieski, assumed leadership of the program with Dr. Teresa Wojcik serving as Assistant Director. The traditional English Language and American Culture camp model (not focused on the arts) returned that year with a new camp at Barlewiczki. From 2012 to 2018, the TEIP program witnessed continued growth with the addition of several new camps: Pinczow, Minsk Mazowiecki, Krakow, Krynica-Zdroj, Siennica, Otwock, and Załęcze Wielkie. In 2013, the Arts-Enriched camp model expanded to a new camp in Otwock. In the 2010s, the Teaching English in Poland program grew to a record seven camps in 2016. In the fall of 2018, the Executive Committee of the Board of Trustees of the Kościuszko Foundation decided that it was best for the Fundacja Kościuszkowska Polska to administer the TEIP program under the auspices of the Kościuszko Foundation. 
Dr. Grazyna Czetwertynska was named the new Director of TEIP.

From the inception, the Teaching English in Poland program was more than its name; it was conceptualized as a reciprocal learning experience for both its Polish and American participants, with each side acquiring knowledge and appreciation of the other's language, culture, and heritage. The Polish students had the unique opportunity to attend lessons taught by native speakers of the English language. The Polish teachers and teaching assistants also benefited from their participation in the camps. For example, they witnessed how American teachers interact with students and use active pedagogical approaches such as role-play and cooperative learning. They also were able to practice their English language skills and expand their knowledge of American culture through conversations with the American staff.

Volunteering as a teacher or teaching assistant at a TEIP camp gave the American volunteers the opportunity to have an international teaching experience. Living and teaching in Poland allowed the American participants to learn firsthand about the Polish culture, language, and cuisine. During the camp, the Polish students and staff shared aspects of Polish culture with the Americans during a special event designated as "Polish Day." Students made presentations about Polish history, cuisine, and music as a way to share their culture with the American volunteers. At the conclusion of the camp, the American volunteers typically attended a three-day excursion during which they visited sites of cultural and historical significance to Poland.

\section{RECRUITING THE TEACHING TEAM}

The Kościuszko Foundation recruits teachers in the United States as volunteers. Teacher participants in the program provide their own travel expenses and organizational fees. Room and board in the Załęcze camp are provided by the Polish Scouting Organization. At the end of the volunteers' stay, they are offered a trip to sites of Polish cultural interest consisting of a few days in Kraków and Zakopane and the opportunity to see world history sites such as Auschwitz.

There are two different groups of Americans recruited to participate in the Załęcze camp, both groups are educators: teachers and teaching assistants. Both groups are recruited through various methods including advertisements through local Polish organizations, posts to various teacher groups (e.g. emails to world language teacher groups), social media promotions, informational tables at local cultural events (such as the Cleveland Dyngus Day celebration), and informational flyers sent to schools with an interest in international mindedness such as International Baccalaureate Schools. Additionally, teaching assistants are also recruited through presentations at universities with teacher preparation programs. To help to properly screen all applicants, two letters of recommendation are required as well as several short answer questions where applicants explain their motivation for participating in the program as well as lessons they would be willing to teach. Often American Staff Leaders will also conduct phone interviews and reference checks to gain further insight into a candidate's abilities.

When recruiting teachers, educators from all disciplines are desirable as the aim of 
the program is to build conceptual understanding and language competence in variety of situations. With this in mind, the program happily accepts a range of educators from college professors to high school art teachers to private music teachers. In the past two years teachers of physical education, science, health, history, math, architecture, and even military science have all shared their content knowledge in English with students. This variety of instructors also adds a variety of content for students who may return to the program year after year. It guarantees that the content will not stagnate and that returning students (and Polish staff) will be exposed to a wide variety of concepts, content, and methods of instruction.

Previous experience working with English language learners is not a requirement to participate in the program as the American Staff leader provides instruction in best practices for teaching English language learners. Participants are provided with a curriculum guide updated yearly by the program's directors. The American Staff Leader also leads virtual meetings where she reviews best teaching practices for English language learners and reviews the language goals of the camp - to help students in the development of their oral language skills, vocabulary, and listening comprehension through meaningful interaction with native speakers. Before camp, teachers and teaching assistants are also provided with training on administering the pre- assessment instrument (The IPT Oral test) and information on what the implications of different levels of IPT achievement will mean for instruction and grouping.

An interesting note on the teaching staff is that at least one quarter to one half of the teaching staff usually have some Polish background. Despite this background, however, few of them may understand or even speak any amount of Polish, so before camp the American Staff Leader also covers the facets of English that are uniquely challenging to speakers of Polish and Slavic languages. The American Staff Leader also describes common cultural differences between Americans and Poles to preempt any cultural misunderstandings. Staff members are provided with a guide from the TEIP Program called "News You Can Use" which attempts to cover the basics of functioning in Poland as well as a brief foray into Polish cultural expectations and norms.

In the months before camp, teachers are asked to begin planning their lessons and it is suggested that they co-plan with their teaching assistant for maximum effectiveness and content knowledge on the part of both instructors. This planning is done virtually as teachers and teaching assistants typically live thousands of miles apart. The staff leader's role is much like that of a traditional administrator in American public schools--to provide instructional leadership and guidance. The staff leader reviews the lesson plans and provides suggestions for instruction and modification, also checking to ensure that teacher's lessons do not repeat content.

Upon arrival at camp, the American Staff Leader continues the traditional educational administrator role by performing classroom observations to provide feedback and if necessary suggestions for change. The staff leader also acts as a liaison between the Polish and American staffs, relaying feedback from the Polish staff in areas where they see the need for change. 


\section{VALUES AND CULTURE AS PART OF LEARNING A LANGUAGE}

The Kościuszko Foundation was created by Polish immigrants and by Americans of Polish heritage, those who have an interest in furthering cooperation and education about both the United States and Poland. The Curriculum Guide for the Teaching English in Poland program (2018) straightforwardly addresses concerns regarding potential imperialistic messages (Odrowaz-Coates 2017) that might be communicated through the teaching of English as a language:

It is not the intentions of the program to Americanize students or to proselytize political or religious concepts and views. Respect for the culture, traditions, and educational standards of Poland must be maintained. Familiarizing the students with American culture should enable them to converse comfortably and intelligently on a variety of American topics. (p. 16)

However, the program does offer plenty of opportunities for socialization into American culture. The theme of the camp changes from year to year but content is molded to reflect the theme. When one of the authors of this paper was in Załęcze, each day of the camp was dedicated to a different famous person, holiday, or event in American history and culture. Children read Edgar Allan Poe and learned about Martin Luther King. They came to understand the importance of the Fourth of July to Americans and how much fun Americans have on Halloween, dressing up in costumes and eating candy. As Polish students are often exposed almost exclusively to British English and culture, it is the goal of the American staff to show the Polish students what the staff considers to be unique and important to them about American culture.

The other source of values and a specific culture represented in the learning English in Poland camp in Załęcze is the scouting tradition associated with the Polish Scouting Organization (ZHP). The place where the camp is organized is a well-known scouting center for both educational opportunities and summer vacations. All of the Polish teachers are scouting leaders, and the entire camp organization is dictated by scouting traditions. Grażyna Truszkowska, one of the camp's teachers, noted, “The values of Kościuszko, such as patriotism, service to others, and tolerance, are also the values of scouting." The values of the Polish Scouting Organization (ZHP) and of the Kościuszko Foundation are essentially the same. It is worth noting that ZHP in years after the Second World War tried to change its core catholic values of education into a more humanistic approach (Kaszkur 2007). As the result of World War II experiences, scouting leaders tried to educate youth in what Ambrosewicz-Jacobs (2016) called a transnational justice set of values. Interestingly, Grażyna Truszkowska cited Janusz Korczak's famous statement: “There are no children, just people”. It shows that the main values at the camp are respect and autonomy of students. Camp staff use play and team work as a learning practice. Each team establishes its own rules and priorities. Staff cooperate with parents. Often families work with the camp staff for a few years sending their children each year for this camp. 


\section{TEACHING LANGUAGE IN A SCOUT CAMP}

It is well recognized that learning depends on the environment (Acker \& Miller 2005). In this case the environment consists of a few buildings in the forest along the river Warta. The forest is the most natural setting for scouting. Many games, songs, and scouting skills relate to the forest. Nature is also a favorite environment for the experiential learning process. Each day of the camp is divided into three different parts: classes in the morning hours, fun and sport in the afternoon, and free time in the evening. American staff is encouraged to use whatever venue is most suitable to their classes and often class activities take place outside. The afternoon activities are always held outside. The structure for outdoor activities is made according to scouting rules, with leaders and teams knowing exactly how to work with each other (Mislia et al. 2016; Radzki 2016; Rajamanikam 2016)

Each age group of children has its own scouting leader, and the American staff teachers are assigned to them. The assigned staff is responsible for creating a group culture with the full participation of students. The curriculum of class is age appropriate and depends on the knowledge of English evaluated at the beginning of the camp. To further try and build a sense of belonging and community each group creates its own unique slogan and a badge in English related to American culture. The scouting routines help to create a relationship between the students and teachers based on working together and diminishing any barriers that may come from the intersection of the American and Polish cultures. This structure for participation in the daily life of the camp and in the learning process follows the recommended teaching practice by Grossman et al. (2009) and is consistent with recommended learning processes in social work (Bergart \& Clements 2015).

Both teachers and students appreciate when all the activities of daily life are connected to the curriculum through informal and formal learning processes. There is no break from learning; all communication has to be conducted in English as the American teaching staff does not speak Polish - even those who do know Polish do not reveal this to the students. In the atmosphere of learning about each other, teachers help students to discover their interests and talents. Later during the concluding program at the camp, students will present their achievements to the whole camp community.

The strong incentive in the learning process at this camp is novelty. Each member of the teaching staff is truly a foreigner. Additionally each year for at least one or two American staff members the visit to Załęcze will be their first time outside the United States or at least off of the North American continent. They come from a different culture and have different reactions to common things present at the camp. They also represent different professions such as teachers and social workers. The best example to illustrate cultural exchange involves food. During the program, there were different dishes that were liked by Polish students and staff. However, these dishes were met with clear distrust by Americans. For example, warm milk for cereal was universally rejected by the American staff and when the Americans served Kraft Macaroni and Cheese to the Polish students, its unnaturally vibrant yellow color was also met with much skepticism and distrust. One food, pizza, was loved by all. Pizza became a sort of 
balm for homesickness among the American staff and there were special trips outside the camp to bring pizza. Polish students loved not only the taste of pizza, but also the ritual of "ordering out" and receiving pizza delivery. Another interesting example of informal learning concerns electronic media. Polish students love exchanging "friendship" on Facebook with American students who work as teaching assistants. This allows them to learn more about each other's lifestyle, travel, music and other interests, which can be discussed later. The practice of using Facebook in learning a language in Poland has been evaluated by Polok and Harężak (2018) with positive outcomes. The use of social media in learning a foreign language was also described by Mondahl \& Razmerita (2014).

This unique learning environment reflects well the discussion among researchers concerning best practices for use in teaching foreign languages (Grossman et al. 2008). Załęcze and the TEIP's instructional program in general are focused on Krashen's hypothesis of acquisition-learning and also on his input hypothesis (Krashen 1988). Thanks to assessments they perform before camp, teachers are aware of their students' abilities and levels and are able to provide appropriate, comprehensible input. Additionally by providing somewhat authentic American classroom contexts of a STEAM (science, technology, engineering, art and math) class or a physical education class, it is hoped that the student will through communication with the teacher and teaching assistant more naturally acquire the English language. This model of teaching the English outside language classrooms is also known as CLIL - Content and Language Integrated Learning (Renau Renau 2016). The teaching method applied in Załęcze is also a good example of a practice in which teachers, through authentic contact with native Polish speakers also learn about the many dimensions of their students' experiences in daily life and culture.

Since teachers are coming from different linguistic and cultural backgrounds than the students, there is no room for negative consequences of professional routine. Teachers need to learn about students through on-going communication inside and outside the classroom. The practicality of the program taught (the content, the English language) facilitates the students' motivation to participate in the learning process. Educators model communication, demonstrate how to ask questions, set and honor professional boundaries and define behavioral structures. The teachers gather information about the students by participating with them in a range of activities inside and outside of the classroom. They can then evaluate the effectiveness, integrity, and complexity of their work during the daily staff meetings according to Grossman et al. (2008).

\section{STUDENTS}

Approximately a hundred students attend the camp. The students are ten to thirteen years old and possess different levels of English knowledge and ability. Most of the students are recruited through advertising for the camp in schools and community centers. About twenty students are recruited from low income families whose participation is funded by The Nidzica Development Foundation "NIDA". American social 
work volunteers are especially interested in this group of students. It is interesting to note that children from this group are fully integrated with the rest of the children; it is difficult to differentiate them from the other children during daily activities. Low-income families do not have to have characteristics of multi-problem families. Although some children from this group may come from families where one parent lives abroad (Farkas \& Romaniuk 2017), they usually are well prepared to live and cooperate with peers in the camp. It is frequently assumed that poverty is linked with behavioral and cognitive deficits among lower income children, but the observation of this group of children contradicts this belief. Children from low-income families were independent and well behaved. They knew how to dress depending on the weather or the special event for the day. They took care of their siblings and other peers from the same group. It seems that low-income families who care to send their children for additional learning also prepare their children well to live in society. The program provides a step up for children of lower income families to form friendships and to participate in preparation to thrive in a global economy through language development skills. Their participation is very important as there is some concern that teaching English can be a source of social and economic exclusion (Odrowąż-Coates 2017). Parents are aware that the English language and socialization to Western culture will help their children in higher education, future employment, and social status (Kasztalska 2014). For these reasons many families invest in teaching their children English as a second language in private schools, training camps, and study abroad programs. Extracurricular technical activities and language classes can increase the wage premium up to $10 \%$ (Bedyk \& Liwioski 2016). Students who completed at least one semester of learning abroad increase their wage premium up to $28 \%$ after graduation (Liwiński 2016). Low-income families cannot afford such additional spending on their children's long-term goals. Social and economic exclusion may start early.

\section{CHALLENGES IN INSTRUCTION}

One of the biggest challenges faced by American teachers and teaching assistants is communicating content in a total immersion situation. Often the American staff leader provides suggestions on how to give the students comprehensible input that matches Krashen's qualifications of being challenging but still comprehensible. The students are ability grouped when they arrive but as teachers often don't have experience working with ELLs (English Language Learners), guidance must be given on the characteristics of each group (i.e. what can be expected of an emerging learner versus an expanding learner according to World-Class Instructional Design and Assessment standards). For ease of communication, each group of Polish students is accompanied by a Polish staff member who serves as both translator and disciplinarian. Polish staff members are mostly certified teachers and university students.

Discipline is another challenge for American staff members. Because of the delicate nature of intercultural interactions, the Polish staff is asked to handle all student discipline matters as they see fit. This can take some adjustment as many American educators are used to being in charge of student behavior in their own classrooms. 
Additionally, American educators must learn on the fly standards and expectations for student behavior and interaction in Polish classrooms while at the same time trying to teach students American standards and expectations. While this arrangement does not lead to much conflict, it can lead to confusing situations for both parties involved.

\section{CONCLUSIONS}

This detailed account of the working of the Teaching English in Poland program illustrates an immersion opportunity to learn English in the context of cultural beliefs and historical events. The program, offered as part of a summer camping experience, is a novel approach to providing English instruction to young Polish students in the informal environment of a scout camp. The inter-organizational cooperation is crucial to the program and has evolved over the years of its operation. Another aspect of this program is the opportunity for students from families of differing incomes to develop skills that will increase social capital and abilities to participate in the global economy. This program is unique to Poland, but the elements of the immersion ideas and administrative alliances can be replicated for different settings and different languages.

FUNDING: This research received no external funding.

CONFLICT OF INTEREST: The authors declare no conflict of interest.

ACKNOWLEDGEMENTS: We would like to thank Grażyna Truszkowska from the Załęcze Wielkie camp for her help in preparation of this manuscript.

\section{REFERENCES}

Acker, Steve \& Mike Miller. 2005. “Campus learning spaces: Investing in how students learn.” EDUCAUSE Center for Applied Research Bulletin 8: 1-11.

Ambrosewicz-Jacobs, Jolanta. 2016. „...wobec rozmiarów Zagłady świat doświadczył ogromnej winy...”. Debaty wokół nauczania o Holokauście.” Studia nad Autorytaryzmem i Totalitaryzmem 38(2): 19-33.

Bedyk, Emilia \& Jacek Liwiński. 2016. “The wage premium from parents’ investments in the education of their children in Poland." Working Papers 2016-14, Faculty of Economic Sciences, University of Warsaw.

Bergart, Ann M. \& Jennifer A. Clements. 2015. "Going to camp together: Lighting the group work fire in a new generation.” Social Work with Groups 38(1): 21-43. https://doi.org/10.1080/01609513.2014.931667

Brown, H. Douglas. 2000. Principles of language learning and teaching. White Plains, $\mathrm{NY}$ : Longman.

Devereux, Peter. 2008. "International volunteering for development and sustainability: Outdated paternalism or a radical response to globalisation?” Development in Practice 18(3): 357-370. https://doi.org/10.1080/09614520802030409

Dörnyei, Zoltán. 1998. “Motivation in second and foreign language learning.” Lan- 
guage Teaching 31: 117-135. DOI: https://doi.org/10.1017/S026144480001315X

Farkas, Kathleen J. \& Jarosław R. Romaniuk. 2017. "Multi-problem families in Poland and a changing, globalized world.” Rodzina wieloproblemowa. Roczniki Socjologii Rodziny 26/27: 7-26.

Gardner, Robert C. \& Wallace E. Lambert. 1972. Attitudes and Motivation in Second Language Learning. Rowley, MA: Newbury House Publishers.

Giota, Joanna. 1995. "Why do all children in Swedish schools learn English as a foreign language? An analysis of an open question in the national evaluation programme of the Swedish compulsory comprehensive school." System 23(3): 307324. https://doi.org/10.1016/0346-251X(95)98861-M

Grossman, Pam, Karen Hammerness \& Morva McDonald. 2009. "Redefining teaching, re-imagining teacher education." Teachers and Teaching: theory and practice 15(2): 273-289.

Guerrero, Mario. 2015. "Motivation in second language learning: A historical overview and its relevance in a public high school in Pasto, Colombia." HOW 22(1): 95-106.

Hayes, David. 2014. Factors influencing success in teaching English in state primary schools. British Council, London, UK.

Hillocks Jr., George. 2009. "Some practices and approaches are clearly better than others and we had better not ignore the differences." English Journal 98(6): 23-29.

Kaszkur, Alina. 2007. Filozofia działania Jacka Kuronia. Instytut Nauk Politycznych. Materiały I Letniej Szkoły Historii Najnowszej. Warka.

Kasztalska, Aleksandra. 2014. „English in contemporary Poland.” World Englishes 33(2): 242- 262. https://doi.org/10.1111/weng.12083

Komorowska, Hanna. 2014. "Analyzing linguistic landscapes. A diachronic study of multilingualism in Poland." Pp. 19-3 in Teaching and learning in multilingual contexts: Sociolinguistic and educational perspectives, edited by A. Otwinowska \& G. De Angelis. Clevedon: Multilingual Matters.

Korczak, Janusz. 2009. The Child's Right to Respect. Strasbourg: Council of Europe.

Krashen, Stephen D. 1988. Second language acquisition and second language learning. London: Prentice-Hall International.

Liwiński, Jacek. 2016. Does it pay to study abroad? Evidence from Poland. Working Papers 2016-25, Faculty of Economic Sciences, University of Warsaw.

Mislia, M., A. Mahmud, \& D. Manda. 2016. “The implementation of character education through scout activities." International Education Studies 9(6): 130-138.

McKay, Sandra L. 2003. "Teaching English as an International Language: the Chilean context.” ELT Journal 57(2): 139-148. https://doi.org/10.1093/elt/57.2.139

Mondahl, Margrethe \& Liana Razmerita. 2014. “Social media, Collaboration and Social Learning - a Case-study of Foreign Language Learning.” The Electronic Journal of e-Learning 12(4): 339-352.

Nikolov, Marianne. 1999. “'Why do you learn English?' ‘Because the teacher is short.' A study of Hungarian children's foreign language learning motivation.” Language Teaching Research 3(1): 33-56. https://doi.org/10.1177/136216889900300103

Odrowąż-Coates, Anna. 2017. “The peaceful expansion of the English language in Europe. A tool of integration or a facet of quiet colonization?" Multicultural Studies 
$1: 115-125$.

Polok, Krzysztof \& Joanna Harężak. 2018. “Facebook as a beneficial tool while used in learning second language environment." Open Access Library Journal 5: e4732

Radzki, Kacper. 2016. „Metoda harcerska w oddziaływaniach zakładu poprawczego.” Zeszyty Naukowe Wyższej Szkoły Humanitas. Pedagogika 12: 173-184.

Rajamanikam, A. 2016. “Scouting and education.” Journal of Applied and Advanced Research 1(1): 1-2.

Renau Renau, Maria L. 2016. "A review of the traditional and current language teaching methods." International Journal of Innovation and Research in Educational Sciences 3(2): 82-88.

Richards, Jack C., \& Willy A. Renandya. 2002. Methodology in language teaching: An anthology of current practice. New York: Cambridge University Press.

Swick, Thomas. 1991. Unquiet Days: At Home in Poland. New York: Ticknor \& Fields Publishers.

Zarębska, Jadwiga. 2010/2011. „Nauczyciele języków obcych w roku szkolnym 2010/2011.” Zespół Wydziału Informacji i Promocji ORE. Retrieved January 10, 2020 (https://womgorz.edu.pl/files/Informacja\%20Pedagogiczna/Nauczyciele jezykow_obcych_2010-2011_13.09.12.pdf).

\section{BIOGRAPHICAL NOTE}

J. Richard Romaniuk, PhD, LISW-S, LICDC, is a researcher and educator. Currently he works as a fulltime lecturer at the Mandel School of Applied Social Sciences. From 2004 to 2015 he worked as a social worker at the Louis Stokes Cleveland Department of Veterans Affairs Medical Center. He also worked in the School of Medicine, Case Western Reserve University as a neuroscientist. His experience at the VA has led him to participate in national VA committees and the National Association of Social Workers in Ohio. He was also involved locally, as a Board member of The Alcohol, Drug Addiction and Mental Health Services (ADAMHS) Board of Cuyahoga County (2010-2017).

Kristin B. Miller, M.L.I.S., Indiana University. Kristin is currently the International Baccalaureate Middle Years Programme Coordinator for Oberlin City Schools where she works with teachers to incorporate international-mindedness into the schools' inquiry-based curriculum. Kristin has been involved with the Teaching English in Poland Program since 2016. In the past she has served as American Staff Leader for the Załęcze camp and she is currently serving as American Staff Leader for its first-ever virtual summer program which aims to connect Polish students with American teachers online during the Covid 19 pandemic. Kristin is also working with the staff of the Kosciuszko Foundation Poland to produce a series of webinars for Polish staff members in the TEIP program.

Mary Kay Pieski , Ph.D. is a recently retired music teacher and served as the orchestra director for the Kent City Public School System. She received an undergraduate degree in Music Education from Marywood University in Scranton, Pennsylvania. Dr. Pieski holds a Master of Music Education Degree in Piano Pedagogy and a Ph.D. in Cultural Foundations of Education from Kent State University. Dr. Pieski has been actively involved in programs that teach English, American Culture and the Arts to children all across Poland for over 25 years. This led her to co-found Eagle-Orzeł Educational and Cultural Exchange, Inc with Dr. Teresa Wojcik, which continues to connect Americans and Poles through 
the Language and Arts. Dr. Pieski is also actively involved in several Polish organizations, professional music associations, and serves in an executive capacity of the Gamma Delta Chapter of the Delta Kappa Gamma Society International. Dr. Pieski is a member of the Orlando Choral Society, a community choir in Winter Garden Florida.

Teresa G. Wojcik, Ph.D. is an Associate Professor of Education in the Department of Education and Counseling at Villanova University. She serves as the director of the graduate program in teacher certification. Dr. Wojcik enjoys working with pre-service and in-service educators and teaches courses in the philosophy of education, methods of teaching, and comparative education. Her research interests include the historical and philosophical foundations of education, Social Studies curriculum, and the preparation of globally competent educators. A former Fulbright scholar in Poland, Dr. Wojcik has a particular interest in studying the history of education in Poland. She has published in a variety of journals including Curriculum Inquiry, Educational Studies, The Social Studies, The Polish Review, and Problemy Wczesnej Edukacji. Dr. Wojcik is co-founder and co-president of the Eagle-Orzel Educational and Cultural Exchange, Inc., a non-profit organization dedicated to creating, facilitating, and supporting cross-cultural exchanges between and among American and Polish teachers, artists, and students.

Kathleen J. Farkas, Ph.D. LISW-Supv. is an Associate Professor of Social Work at the Jack, Joseph and Morton Mandel School of Applied Social Sciences, Case Western Reserve University, Cleveland, Ohio USA. She has extensive clinical and research experience in the areas of mental health and addictions assessment and treatment. Dr. Farkas a long time interest in substance use issues among older adults and women and her work has focused on addictions and mental health issues among those incarcerated in jails and prisons. Recently she has been involved in research, teaching and service efforts using animal assisted interventions in mental health and addictions. She is the chairperson of the Mandel School's direct practice faculty as well as the specialization faculty for substance use disorders and recovery.

\section{Postscript}

Significant changes in the administration of the TEIP program have taken place since the time of the writing of this article. Dr. Mary Kay Pieski and Dr. Teresa G. Wojcik no longer serve as the Director and Assistant Director of the program, respectively. They are no longer affiliated with the Kosciuszko Foundation.

OPEN ACCESS: This article is distributed under the terms of the Creative Commons Attribution Non-commercial License (CC BY-NC 4.0) which permits any non-commercial use, and reproduction in any medium, provided the original author(s) and source are credited. 